\title{
Use of mobile phones as supplementary teaching and learning tools to learners in South Africa
}

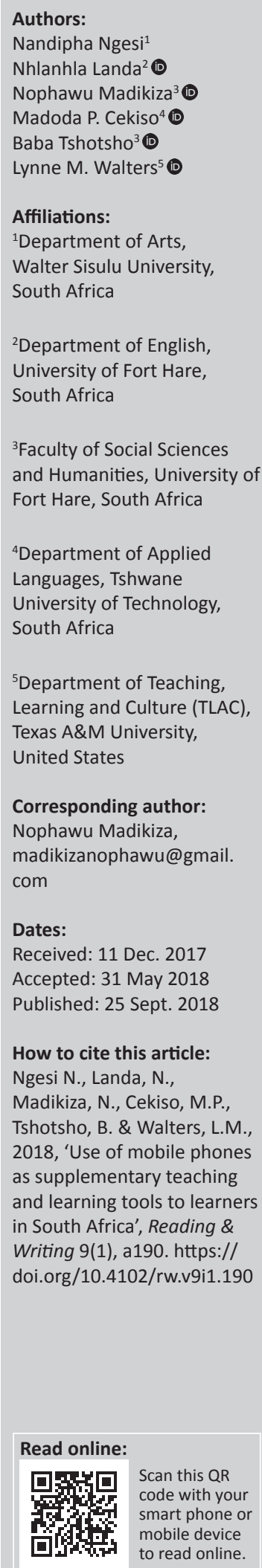

Corresponding author: Nophawu Madikiza, madikizanophawu@gmail. com

Dates:

Received: 11 Dec. 2017 Accepted: 31 May 2018 Published: 25 Sept. 2018

How to cite this article: Ngesi N., Landa, N., Madikiza, N., Cekiso, M.P. Tshotsho, B. \& Walters, L.M., 2018, 'Use of mobile phones as supplementary teaching and learning tools to learners in South Africa', Reading \& Writing 9(1), a190. https:// doi.org/10.4102/rw.v9i1.190

\begin{abstract}
One of the major challenges in teaching English to speakers of other languages is the issue of inadequate contact time between teachers and learners and between learners and comprehensible English language input. This paper emanated from a burning desire to help learners in South African educational institutions, especially those in remote areas, increase the opportunity for learner-teacher-content contact. The deployment of mobile phones, as tools to supplement teaching and learning off-campus and after school hours, is presumed in this study to be one attempt to increase contact time for learners. A qualitative research methodology, which is interpretive in nature, was used. The study used a descriptive case study research design. It used a sample of 44 learners, drawn from Grade 9 English First Additional Language learners in one school in the Eastern Cape. The participants were sampled, using purposive and volunteer sampling techniques. Mobile phones were used to collect data, which was in the form of short message services (SMSs) and Mxit messages. A questionnaire with open-ended questions was also used to collect data about learners' perceptions of the use of these devices in the educational process. The data were analysed by incorporating elements of both content analysis and discourse analysis. Despite the fact that some participants were of the view that SMS would corrupt their language and spelling, findings indicate that most SMS and Mxit texts produced by participants displayed full sentences, punctuation marks, correct spelling of most words, acceptable grammar and proper sentence use. Further, findings indicated that while SMS and Mxit communication were largely characterised by short hand and informal writing, when learners were aware that they were using these platforms for learning purposes, the traditional rules of formal writing applied. We conclude that mobile devices can improve the language acquisition of second language learners. We recommend consideration of the official inclusion of mobile devices as supplementary learning tools in the learning programme in South Africa.
\end{abstract}

\section{Introduction}

The use of mobile phones for teaching and learning purposes in some schools in South Africa is not a new phenomenon. There have been trials focusing on the use of short message services (SMSs) (Chaka \& Ngesi 2010; Chaka, Ramothea \& Ngesi 2010). Elsewhere, Hagos (2008), Ling and Baron (2007), Meurant (2007), and Wood et al. (2009) have reported on the use of SMSs and instant messaging to support teaching and learning. Texting, the common term used for writing and sending SMSs and instant messages (IMs), is, therefore, a common phenomenon in experiments to improve teaching and learning.

Despite their potential to aid the teaching and learning process, mobile phones are still disliked and outlawed in schools in South Africa. This has been attributed to two major issues: the likelihood that they will be disruptive in classrooms and misused by learners (Fried 2008). All major stakeholders in the education sector believe that the use of mobile phones to have negative consequences. Instances of misuse have been reported in some schools in South Africa (Bosch 2008; Ford \& Batchelor 2007). More specifically, the source of mistrust of mobile phone technology in the classroom stems from its potential contribution to the deterioration of grammar, poor language use, bad spelling and a lack of good writing by learners, mostly of the English language (Chaka et al. 2010; Tagliamonte \& Denis 2008; Vosloo 2009; Wood et al. 2009).

All this, however, does not mean mobile phones are not in the classroom (Junco 2012; Sana, Weston \& Cepeda 2013). The addiction of learners, and the young people specifically, to mobile

Copyright: (C) 2018. The Authors. Licensee: AOSIS. This work is licensed under the Creative Commons Attribution License. 
phones in South African schools and institutions is unquestionable. Even with stringent rules preventing the bringing of mobile phones to high school, these still found their way into the classroom. This makes the mobile phone a technological gadget of choice among the youth of schoolgoing age. This also points towards the potential of these devices in aiding the teaching and learning process (Ling \& Bertel 2013).

According to North, Johnston and Ophoff (2014), the main reason South African students use mobile phones is for socialising, as well as for safety and privacy, less through making phone calls than through text messaging. Most young people never turn off their phones, use SMS and/or instant messaging (IM) in class and always check their phones for missed calls or messages (North et al. 2014). In fact, no other age group sends anywhere near the number of text messages as teenagers and young adults (Ling \& Bertel 2013).

In a South African context, there may be some rules on not bringing the mobile phones to class in many schools. However, recently, in some provinces like Gauteng, the Department of Basic Education has provided all high school learners with iPads. The Mail \& Guardian dated 02 April 2012 reported that iPads have brought about a new attitude to learning at schools in the Gauteng province. They further reported that the use of iPads in schools, whether it is a disadvantaged or private school, vastly improves pupils' engagement and involvement in lessons. Responding to an interview with the Mail $\mathcal{E}$ Guardian, Chairperson of the Programme for Educational Tablets in Schools (Pets) Foundation, Michael Rice, told the Mail E Guardian that the cultural and psychological issues around information communication technology (ICT) in schools cannot be underestimated, yet have hardly been recognised or researched (Mail E Guardian 2012).

Therefore, this study is very crucial as it adds to the literature on the increasingly growing debate on whether to integrate mobile phones in the education system of South Africa and of several other African countries. It grapples with the major issues in the allowance of cell phones in class, especially in the province of Eastern Cape where the study was conducted. The findings of this study might change the attitudes of education officials, governing bodies and teachers towards welcoming initiatives to introduce ICT into classrooms. Further, it gives useful insights into the usefulness of mobile technology in both secondary school and university education.

\section{Research problem}

Mobile phones are a technological device of choice among both the in-school and out-of-school youth in South Africa (Kreutzer 2009). Mobile phones come with very important platforms, among them SMSs and Mxit. The latter has become the preferred mode of personal communication and chatting for the youth in South Africa and is used by $92 \%$ of South African students. Facebook Messenger, with 55\%, and Blackberry Messenger (BBM), with $48 \%$, are a distant second and third, respectively (Shapshak 2015a, 2015b). At the same time, schools and all educational institutions are facing challenges of limited resources and time constraints where contact between learners and instructors and with course content are concerned.

We set out to explore the potential of mobile phones to improve students' access to learning material off the school environment. The study sought to explore ways of increasing contact between learners and content in the target language. The question that guided the study was whether mobile phones could be used as supplemental teaching and learning tools to learners of English as a first additional language (EFAL). We were also interested in establishing the views of learners pertaining being taught through mobile phones after the standard school hours and on the impact of these devices on the educational process.

\section{Theoretical framework}

The study of essay content was premised on discourse analysis (DA), which comprises a series of interdisciplinary approaches to the analysis of discourse. As stated by Brown and Yule (1983), DA includes pragmatics, conversation analysis (CA), ethnography of communication, interactional socio-linguistics, systemic functional linguistics (SFL) and critical discourse analysis (CDA), among others. Specifically for this study, DA also comprised elements of conversation theory, presence learning, relationality (Chaka \& Ngesi 2010; Chaka et al. 2010), incidental learning (Kabilan, Ahmad \& Abidin 2010), new media writing (Chaka \& Ngesi 2010), cultural historical activity theory (Kang \& Gyorke 2008; Rambe 2010) and exchange theory (Hatter 2002; Shi et al. 2006).

DA is associated with social action as influenced by ideology, making it closely linked to pragmatics. Discourse analysis functions to construct the social world (Adjei 2013). It helps the analyst understand form, meaning and mental processes that go into discourse construction and use (van Dijk 1995).

The sub-research question for the pre-participation questionnaire was: What are the participants' views about being taught and learning through mobile phones and Mxit before participating in the study? The questionnaire schedule in this regard had five items (questions) which were meant to elicit responses, providing further details to the sub-research question. The latter was part of the main research question of the study which was formulated thus: Can mobile phones and Mxit be used as mobile supplemental teaching and learning tools to Grade 9 EFAL learners at James Kobi Junior Secondary School (JKJSS) outside school hours? Participants in this study were then required to respond to these five items. 


\section{Literature: A brief review}

In South Africa, education inequality remains one of the indelible legacies of the apartheid era segregationist policies. For poor resource communities, and in rural settings where education systems cannot meet societal demand, rapidly evolving mobile technology is providing new opportunities for learning. South Africa has been embracing these devices to expand educational curricula, to increase efficiency and quality alike (EdTechnology Tours 2017).

Mobile devices are much less cost prohibitive and less infrastructure heavy than computers, which gives them the greatest potential for delivering ICT-based education to marginalised learners, the poor, refugees and migrants, and those living outside of urban areas. Mobile technology represents an important avenue by which to reduce the gap between the poor and the rich in contemporary society where access to knowledge and information is increasingly vital (van Weert 2005).

With the advent of smart phones and other small, inexpensive and powerful tools, a newer term is gaining momentum in education: mobile learning, or m-learning. Similar to e-learning, m-learning refers to any learning that is mediated through the use of a mobile device (Churchill, Lu \& Chiu 2014). Godwin-Jones (2017) argues that mobile learning is expanding the learning environment and that mobile phones 'do not seem likely to be going away anytime in the foreseeable future'. The proof is in the numbers. Mobile phone use has gone beyond expectations, with $89 \%$ of South Africans owning a mobile. South Africa is also the continent's leader in app downloads, usually an indication of higher smartphone adoption, with $34 \%$ of phone users making downloads from app stores (World Economic Forum 2017).

The education potential of mobile phone technology is being hyped. Recently, the US-based television channel CNN declared that mobile technology had 'immense' potential to transform Africa's 'dysfunctional educational system ... as mobile phones - cheaper to own and easier to run than PCs - gain ground as tools for delivering teaching content.' (Parr 2013)

Studies have been conducted into the effectiveness of mobile phones and the texts, or SMSs, they carry in enhancing teaching and learning in an academic environment (Chaka \& Ngesi 2010; Oyinloye 2009; South African institution for distance education [SAIDE] 2008). They have found that the major function of the mobile phones in an educational context is purely logistical. Students receive notices about learning schedules, examination time tables and venues, course marks and other announcements. Stone and Briggs (2002) established that learners preferred SMSs, specifically the free messaging service WhatsApp communication to electronic mail. Al-Khalifa (2008), for example, established that, by using their mobile devices, students were able to receive prompt course information. Further, the study established that $93 \%$ of the students preferred receiving announcements via an SMS, like Twitter, to visiting the course blog for updates.

Mobile phones also gave students access to course materials. Because of widespread poverty, many South African students are unable to afford a hard copy of the books required for a course. However, they can download the text and related readings, videos and websites on their mobile phones. They also can access the Internet to expand and deepen their knowledge of course content. According to Ed Technology Tours (2017), mobile devices can provide students with the ability to access and easily use course materials while on the go. They 'enable just-in-time, informal, chunk-sized learning that is adapted to a South African context of long commutes and cramped family settings in townships'. Learners need to be able to study and read in 'short, effective bursts' when they can, to leverage those moments and turn them into learning opportunities (Ed Technology Tours2017).

Researchers in a SAIDE study established that learners could effectively use mobile phones to collaborate with their counterparts, using a communal style of learning that is most compatible with the culture of South Africa. Students also can communicate with scholars through SMSs, sending images and even making phone calls to renowned experts (SAIDE 2008). A project called Dr Math, for example, connected 30000 high school students with undergraduates at the University of Pretoria's Faculty of Engineering for homework help. 'For many children in South Africa, this is the most qualified tutor that they will have access to', says Steve Vosloo, a mobile learning specialist at UNESCO (2017).

More recently, several scholars have conducted studies in which they established that mobile phones improved the performance of learners when properly integrated into the teaching and learning processes (Haruna et al. 2016; Jairus et al. 2017; Kimura 2007). And students are ready to embrace mobile learning (Chaka \& Govendor 2017). Another study by Sharples, Taylor and Vavoula (2005) revealed that using mobile devices can 'facilitate knowledge-centred learning by providing efficient and inventive methods to which students can learn with understanding - meaning that they deepen their understanding of a specific subject matter than merely memorising large amounts of information'. The ability to create and share content through mobile phones and the online apps that come with them, empowers learners in their learning and gives them a sense of pride and responsibility (Laurillard 2007; Palalas 2011).

There is a limit, however, to what students and instructors can do using mobile phones. The impediments to doing certain types of academic activities exclusively on a mobile device, challenge even the most creative faculty; although elements of these courses may be used on a mobile device, the entire course is not something that could be effectively conducted on a mobile device. Written assignments are especially problematic. While Oyinloye (2009) and Chaka and Ngesi (2010) have experimented with using SMS for 
writing purposes, other scholars note that most high school and college courses require some form of lengthy written work that is too difficult to complete on a small, hand-held device. In this case, instructors might design less textdependent assignments, such as blogs, podcasts or digital stories, or provide students with access to more traditional devices, that is, laptops or desktop computers. Researchers have also experimented with Twitter and Facebook as supplemental tools for teaching and learning (Al-Khalifa 2008; English \& Duncan-Howell 2008; Project Tomorrow 2010; Schroeder \& Greenbowe 2009). Further, Facebook has also been found to be a useful tool for supplementary teaching and learning (Schroeder \& Greenbowe 2009). The aim with Facebook would be to encourage learners to discuss course content outside of the controlled classroom context.

English and Duncan-Howell (2008) concluded that a tool like Facebook could be used for affective purposes, such as group reinforcement, encouragement and support, which would be very appropriate in the South African context. Of course, the use of Facebook for learning purposes comes with such challenges as tensions between lecturers' teaching styles and student notion of learning, challenges of redundant postings, intergenerational tensions between lecturers and students, constraints of time and limitations of collective responsibility (Rambe 2010).

Borau et al. (2009) concluded that Twitter was a useful tool for learning communicative and cultural competence anytime and anywhere and a convenient medium for social and collaborative learning if used appropriately. Besides, Twitter served as a quick and easy platform for informal communication and for reading (Borau et al. 2009).

Mobile phones have not been embraced enthusiastically by everyone in the educational community. The National Association of School Governing Bodies (NASGB), in fact, called for a ban on the use of cell phones in South African schools (Dunlop 2017). Supporters of the ban point to the potential for student distraction and classroom disruption. Such challenges as misbehaviour, online bullying, issues of privacy and self-representation, and addiction to social networks have been raised as well. Making course materials easily usable in a multitude of formats (i.e. both text and audio) can make it possible for students to complete their reading while on the go, but there are disadvantages to this as well. It is not as easy for students to actively take notes while reading in this way. Students may be multi-tasking (e.g. driving while listening to the text reading for the day), which will likely result in a lack of reflection and less deep processing of the material (Burak 2012).

One of the greatest concerns is that the abbreviated text style of English, used on mobile phones, will make its way into official school writing and examination scripts. Called SMS language, it resembles code rather than language. It may be incomprehensible to speakers of standard English, which is associated with academic and professional achievement and the educational systems of English-speaking countries worldwide (Weiss 2009). Some scholars believe that SMS language used on mobile phones will degrade their students' language usage. High school teachers of English as home language for Afrikaans-speaking students in the Western Cape viewed SMSs as having a negative effect on students' writing, reflected in incorrect punctuation, non-conventional spellings and shortened sentences. The educators expected this to lead to poor grades and diminished knowledge of standard English (Geertsema, Hyman \& Van Deventer 2011).

Other researchers determined that this was not the case. Freudenberg (2009) found that young people were avid users of SMSs and proficient in text speak when sending and receiving messages and chatting with friends. Despite this, the samples of written work did not contain a great number of incidences of SMS language, but they could produce written work that adhered to the formally approved standards of written high school English. A number of SMS speak features were indeed present in their formal written work, which indicates that mobile phone usage had some impact on their written work. However, not all of the nonstandard features could be attributed to the influence of SMS speak, as some of the spelling and punctuation had been noted in the written English of learners even before the advent of the mobile phone (Freudenberg 2009). The evidence suggests that grammatical violations in the text messages of children, adolescents and adults do not reflect a decline in grammatical knowledge. According to the Yoza project website (https://m4lit.wordpress.com/about-the-project/) which details a programme that uses mobile phones to teach children to read and write (Dunlop 2017):

Remember that this is generation txt, who apparently can't spell or write properly..., but what is clearly evident is that when they read they know their spelling from their splng.

Researchers concluded that the general lack of SMS speak in the written work of these learners is the result of being able to assess when it is and is not appropriate to use a certain variety of language: Young people seem well aware that different types of communication require different ways of writing. As Thurlow, Lengel and Tomic (2004:124) explain:

Standard English may be the agreed norm for writing a college essay or a business letter, it's by no means the norm when speaking on the street - no one really speaks like they write!

As long as young writers can maintain this awareness, then the violations of grammar common in digital communication need not be perceived as a reduction in writing skill, but rather as the addition of an alternative, casual style to the writer's repertoire.

\section{Methodology}

We used a descriptive case study research design, as we were interested in participants at case level, and relied on a descriptive framework for analysis of data. One of the most important features of a case study is its flexibility to allow 
examination of 'a phenomenon in its natural setting' and allowing use of many methods in the collection of data (Baxter \& Jack 2008; Benbasat, Goldstein \& Mead 1987:370; Johansson 2003; Rowley 2002). A case study inquiry, such as the one completed here, also involves intense descriptions of a phenomenon or case (Henning, Van Rensburg \& Smit 2004).

Given the above design, the methodology is qualitative and interpretive in nature. This was informed by the qualitative data that the study relied on, which consisted of open-ended survey questions and discourse made up of the elements of essays: written words, sentences and short paragraphs. Words and sentences were the short stretches of discourse, while shorter paragraphs were longer stretches of discourse (Brown \& Rodgers 2002; Henning et al. 2004).

Data were collected using two methods, a document analysis and questionnaires. Document analysis was used to collect data from mobile phones, while questionnaires were administered to the participants. There was a pre-participation questionnaire and a post-participation questionnaire.

\section{Sample}

Participants were 44 learners sampled from a group of 198 learners doing EFAL in Grade 9 at JKJSS in Mthatha district of South Africa's Eastern Cape province. James Kobi Junior Secondary School, which serves grades 1 to 9, draws learners from the Northcrest, a township $5 \mathrm{~km}$ east of Mthatha. Some learners also come from several neighbouring informal settlements. At this school, English is taught as a first additional language. Traditionally, this is equivalent to English as a second language and English as a medium of instruction, as applied to South Africa before 2001. Students and teachers are expected to use English as a medium of instruction (Department of Education 2003).

Unfortunately, limited resources do not allow for the fulltime use of English to facilitate learning. With six hours per day contact with the teachers, students do not have adequate exposure to a comprehensible English language input. Based on the belief that mobile phones could supplement teaching and learning after school hours, we incorporated the devices in the lessons of the experimental Grade 9 group. Mobile phones were easily accessible to these learners who already had these technological tools.

The first additional language aims at improving learners' acquisition and use of the English language. The participants were also sampled, using the volunteer sampling technique, which refers to a scenario where participants volunteer to participate in a study (Strydom \& Delport 2001).

\section{Instrumentation}

Two sets of instruments were used to collect data in this study. The first set consisted of mobile phones and Mxit, while the second set comprised two types of questionnaires. The mobile phone data were in the form of SMSs, whereas the Mxit data were in the form of mobile instant messages (MIMs). The data were collected in five distinct phases. The third and fourth phases concentrated on MIM data, while the last phase involved administering a post-participation questionnaire.

The pre-participation questionnaire consisted of the following five open-ended items:

- What do you use SMSs and Mxit for when you are at home?

- Do you think you should be allowed to use mobile phones (cell phones) and Mxit at school? (Provide a reason for your response)

- Do you think mobile phones and Mxit can be used for teaching and learning purposes both at home and at school? (Provide a reason for your response)

- Do you make use of the SMS and Mxit language in your school work? (Provide a reason for your response)

- Should the language used in SMSs and Mxit be taught at school? (Provide a reason for your response).

For the SMS data, participants were asked to write two short paragraphs (in English) on the following topics: self-esteem and my role model. In this case, the MIM data were derived from two short English paragraphs and Mxit sessions on English adjectives, synonyms, idioms, direct and indirect speech. The topics for the two short Mxit paragraphs were: (1) what you liked and did not like about the teachers' strike,

(2) that day was a mess or (3) what I like about Mxit.

The post-participation questionnaire comprised the following open-ended item: Write two short paragraphs about what you liked and what you did not like about using SMSs and Mxit for teaching and learning in the project in which you participated. Except for questionnaires which were administered at school, all the other activities in this research project were given to participants through the two respective technologies (SMSs and Mxit) for them to do at home. Thus, the researchers enlisted the services of at least four assistant researchers to help conduct this research study. The study itself spanned 30 weeks spread over one year (2016).

\section{Data analysis}

The data in this study were analysed by incorporating elements of both content analysis and DA. Content analysis refers to analysing the content of data texts with a view to establishing the relationship that content items have with one another. It entails coding and sorting the data content into relevant categories (e.g. messages, themes and patterns) that can be developed into theoretical constructs (Brown \& Rodgers 2002; Henning et al. 2004).

For the current study, the data content comprised words, phrases, sentences, paragraphs and chat exchanges produced by participants in the form of questionnaire responses and through SMS and MIM texts. In the context of this study, DA 
involves two senses. In the first sense, it is about working on data and analysing it as part of discourse (interrelated chunks of extended speech, writing, conversation or communication and not just discrete words, phrases, sentences, paragraphs and conversational exchanges) (see Brown \& Rodgers 2002; Henning et al. 2004; also see Cameron 2001; Sinclair \& Coulthard 1992; Stubbs 1983; Tannen 1984). In the second sense, it refers to analysing statements, exchanges or language specific to certain contexts of use.

In relation to the present study, written words, sentences, paragraphs and chat exchanges produced by participants are viewed, on the one hand, as part of a larger discourse constituting either speech, writing, conversation or communication. On the other hand, participants' words, sentences, paragraphs and chat exchanges, especially in connection with SMSs and MIMs, are perceived as forms of discourse mediated by both mobile phones and Mxit. That is, in this context, participants' words, sentences, paragraphs and chat exchanges are regarded as part of the discourse of SMS and the discourse of MIM, respectively. Therefore, this data analysis method consists of a typology of both classical writing features and new media writing and/or new mobile literacy features as mediated by new media technologies like mobile phones and Mxit (Chaka \& Ngesi 2010; Chaka et al. 2010).

\section{Ethical consideration}

Permission to conduct the study in the study area was obtained from relevant authorities, the principal of the school and the schools district manager. Both learner participants and parent participants signed informed consent forms. Further, participation in the study was voluntary and the participants were made aware of their rights, including the right to withdraw from the study at any point should they deem it necessary.

\section{Presentation of findings}

The pre-participation questionnaire for high school learners focused on the participants' use of SMSs and Mxit at home, the views of learners on whether or not mobile phones should be allowed in school, what learners thought of the use of mobile phones for teaching and learning, both at school and at home, and the challenges the learners assumed could be associated with the use of mobile phones for teaching and learning of EFAL. A total of 44 participants ( 31 boys and 11 girls) participated in the high school pre-participation questionnaire. The specific sub-research question pertaining to the pre-participation questionnaire was: What are participants' views about being taught and learning through mobile phones and Mxit before participating in the study?

The interview session began with the following sub-question:

\section{What do you use short message services and Mxit for when you are at home?}

Responding to this question, 35 participants, out of 44 , mentioned that they used SMSs and Mxit for communicating with friends, for staying in touch with friends, for meeting new friends and for fun, while 8 participants said that they used these two applications for getting information. One participant was not sure why he was using these two applications. Participants also cited that using these two tools for sending text messages was cheap and affordable. The following are six unedited responses from the participants:

'I use SMSs and Mxit to stay in touch with my friends and to meet new friends.' (P1, Female, Grade 9)

'I use Mxit for chating for fun and know wat I don't know and ask about school works or what has been done at school when I don't came like home works.' (P13, Female, Grade 9)

'We use Mxit at home because if we can carch our friends and talk.' (P44, Male, Grade 9)

'I use SMSs and Mxit at home so that I can get knowledge and information in a small cost of airtime/money expence. I use Mxit to keep updated from the school work from my class mates, for example, when I was sick and didn't go to school.' (P12, Male, Grade 9)

'I use Mxit to communicate with others, for example, friends family or classmates. And it's very cheap for young people and old people. If you want to communicate cheap.' (P21, Male, Grade 9)

'I use SMSs when i need something or when i miss someone. I use Mxitinorder to have a chance to talk to my friends without calling them. I also use Mxit when I need help on my school work so they help me.' (P4, Female, Grade 9)

With regard to the above sub-question, participants indicated that they used SMSs and Mxit at home for chatting with friends, for finding new friends, for having fun and for getting information and knowledge. They also highlighted the cheapness or cost-effectiveness of these applications. This means that these two applications serve as virtual platforms for chatting, friendship, fun, establishing new friendships and for sourcing information and knowledge for participants. In the first instance, these two technologies - as examples of social media technologies - tend to function as socialisation platforms for participants; in the second instance, they appear to be information and knowledge sharing tools for participants.

\section{Do you think learners should be allowed to use mobile phones (cell phones) and Mxit at school? (Provide a reason for your response)}

In response to the above question, 29 participants were of the view that learners should be allowed to use mobile phones and Mxit at school, while 15 of them were against this view. The following are the five unedited sample responses to this item:

'Yes, because us as learners sometime we learn things maybe we discover things we did not know.' (P4, Female, Grade 9)

'Yes, because if you are left by your transport and you don't have enough airtime to make a phone call you use Mxit/SMS.' (P17, Male, Grade 9)

'Yes, if it would be for learning, I think it could be cool. Communicating with your teacher without noise.' (P6, Male, Grade 9)

'No, because it is not in the school timetable, and it is disturbing because most of the learners don't have phones and some are not allowed to Mxit.' (P10, Female, Grade 9) 
'No, because the learners use phone for bad things and listening to music while the teacher teaching.' (P3, Male, Grade 9)

'I don't think it is good for learners because some may use them in a wrong way in such a way that they do bad things and that makes the word of 'Mxit' dirty, while Mixt doesn't have a problem but it's just that it goes with your self-discipline.' (P13, Female, Grade 9)

Responding to the above sub-question, participants provided a variety of responses. Firstly, when asked if learners should be allowed to use mobile phones and Mxit at school, most participants felt that these two technologies should not be used at school because they were disruptive. They also indicated that these technologies were not part of the school curriculum. Secondly, when polled about the use of mobile phones and Mxit for teaching and learning purposes at home and school, a majority of the participants expressed the view that they should. They mentioned that they could be used for additional and/or follow-up teaching and learning, for providing space for learners who are scared to talk in the presence of other learners and for enabling learners to communicate with their teachers.

\section{Do you think mobile phones and Mxit can be used for teaching and learning purposes both at home and at school? (Provide a reason for your response)}

In responding to this item, 35 participants said that mobile phones and Mxit could be used for teaching and learning purposes both at home and at school, whereas seven of them believed that they could not be used for teaching and learning purposes. Two participants were not sure. The following is the unedited sample of participants' responses to the above item:

'Yes, because when we miss understood something at school we can ask it again through Mxit.' (P5, Female, Grade 9)

'Yes, I think it should be caurse at schools we teach about technology how it works and at Homes it should be the same because when you have close friends they mybe help your parents understand it.' (P17, Male, Grade 9)

'Yes, I think it's a good thing to use Mxit for teaching because we can learn more prove the point that older parents think Mxitit's not good for use.' (P41, Male, Grade 9)

'Yes, because some learners get afraid to ask questions about what they haven't understood during the lesson at school and they get a chance to ask their teachers through Mxit and SMSs.' (P36, Male, Grade 9)

'Yes, because it can teach children/kids to communicate maybe a person does not have enough airtime and has only one SMS that person can use abr to communicate.' (P2, Female, Grade 9)

'Yes becauselet's say I am at home, Idon't know a answer for my home worki use Mxit and at home I will talk to my teacher and say I did not understand your question earlier.' (P33, Male, Grade 9)

'No, it must be used at home because it will help know other things and understand them correctly when you are at home with on one disturbing and at school it must not be used as i said it will disturb.' (P20, Female, Grade 9)
'No, because it's inappropriate and it will distract in our learning areas and spelling, if you may not concentrate in school and at home.' (P16, Female, Grade 9)

In response to the above question, the majority of learners indicated that mobile phones and Mxit can be used for teaching and learning purposes both at home and at school. They saw Mxit as a good strategy to supplement the lessons taught at school. They also mentioned that since we live in the world of technology, sharing technology with their parents at home will also benefit their parent and dismiss the misconception that old people do not like technology. Learners also mentioned that SMSs and Mxit are good for independent learning as they assist those learners who are scared to ask questions in class.

\section{Do you make use of short message service and Mxit language in your school work? (Provide a reason for your response)}

In relation to this item, 37 participants indicated that they did not make use of SMS and Mxit language in their school work, while five participants agreed that they did use it. Two participants were not sure. Below are the unedited sample responses from the participants in response to the above item: 'No, because our teachers don't allow it.' (P25, Male, Grade 9)
'I don't because I am able to separate SMS/Mxit with my school
work.' (P27, Male, Grade 9)

'No, because we are not allowed to write that language at school.' (P8, Male, Grade 9)

'No, there's no reason for that a person can easy learn the language. And also spellings would not be correct.' (P43, Male, Grade 9)

'No, because I know that some teachers do not understand the language very well.' (P11, Male, Grade 9)

'No, because the other teachers might not understand it and they might not like it and it might confuse me too I won't understand or the spelling of other words.' (P5, Female, Grade 9)

'No, because I think it is no allowed because is not a school language or I write when I am mistaken.' (P3, Male, Grade 9)

'No, because the Mxit language is for cell phones only. I don't make any mistake because I know that I have to use full words not like Mxit.' (P30, Male, Grade 9)

'Yes, sometimes I use it by mistake and short my words not finish them.' (P1, Female, Grade 9)

'Yes, but not all the time but if I did that it may be a mistake. I didn't mean to do that.' (P23, Male, Grade 9)

'Yes, because there is a word your don't now bat your now or Mxit word.' (P7, Male, Grade 9)

'Yes, sometimes that happens a lot I think what causes that is to much mxing can cause that.' (P44, Male, Grade 9)

The above responses reflect learners' views about the use of SMS and Mxit language in their school work. Most participants said that they hardly used such language in their school work. However, others hinted that they did. This shows that learners were aware of the context in which SMS and Mxit language was supposed to be used. Therefore, this does not rule out the positive benefits of SMS and Mxit, as long as learners are made aware of the contexts in which these are supposed to be used. 


\section{Short message service English paragraphs}

Adding to the information solicited through interviews, participants were asked to write one short paragraph (in English) on the following topic, Self-esteem, using their personal mobile phones. The aim was to address the following two sub-questions:

- Can SMSs serve as a medium for writing short English paragraphs by JKJSS's Grade 9 EFAL learners outside school?

- Is it possible for SMSs to function as a platform for instant feedback to JKJSS's Grade 9 EFAL learners outside school?

Figure 1 portrays two unedited sample SMS paragraphs (together with their relevant feedback and scores) on the topic, self-esteem, and the time at which they were sent to the research team's mobile phone handset.

Figure 2 is a participant's sample SMS paragraph together with feedback and a score on self-esteem.

In responding to the SMS topic, participants produced a variety of short paragraphs. For example, participants' SMS paragraphs on the topic, self-esteem, ranged from substantial paragraphs to mid-range paragraphs to one line and two-line paragraphs. These paragraphs were sent to the one of the researchers' mobile phone handset at different times in the evening, as reflected in Figures 1 and 2 . Above all, each participant's paragraph on the topic was accompanied by a comment and a grade. As exemplified by Figures 1 and 2, most of the SMS paragraphs produced by the participants displayed, within the SMS environment, the following classical writing features, namely, full sentences, punctuation marks, correct spelling of most words, acceptable grammar, appropriate use of words and proper tense use. Moreover, few of these SMS paragraphs

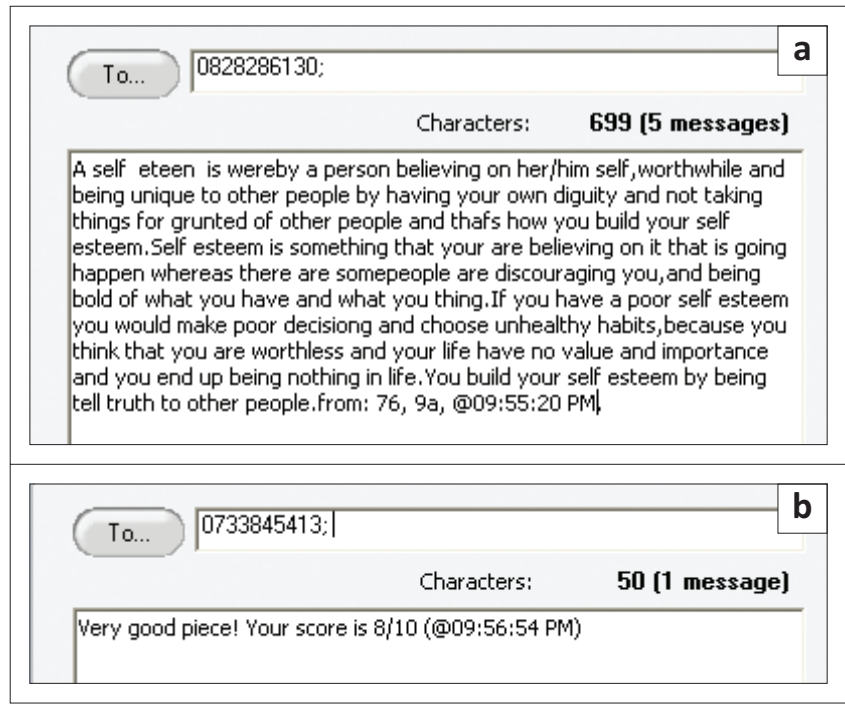

Note: The phone numbers of the participants are intentionally removed to ensure their anonymity.

FIGURE 1: (a) Sample short message service paragraph submitted by learner to teacher; (b) sample comment sent to learner from research team's phone. even employed some linking words or transitional markers and what could be viewed as introductory, supportive and concluding sentences. Of course, some of the paragraphs had certain words misspelt; did not use an apostrophe where it should have been used; did not have capital letters at the beginning of the sentences; and used capital letters within sentences when this should not be the case; or combined two words into one word through the use of an ampersand (the symbol $\mathcal{E}$ ); had run-on sentences and others displaying incomplete sentences and/or thoughts. A critical point to highlight with respect to these SMS paragraphs is that, in line with the model of analysis and the theoretical framework employed in this study, they are instances of a conversation and new media writing. As instances of the former, these paragraphs are bound to exhibit such features as outlined above.

\section{Mxit's mobile instant message English paragraphs}

In addition to SMS paragraphs, participants were asked to write one short MIM paragraph using Mxit on the following topic: what you liked and did not like about the teachers' strike. The paragraphs were intended to respond to the main research question and two sub-research questions formulated as follows:

- Can mobile phones and Mxit be used as mobile supplemental teaching and learning tools to Grade 9 EFAL learners at JKJSS outside school?

- Is it possible for MIMs to function as a platform for instant feedback to JKJSSs Grade 9 EFAL learners outside school?

The following two unedited sample MIM paragraphs (accompanied by their relevant comments and scores) indicated how participants responded to the topic: What you liked and didn't like about the teachers' strike?

As is the case with SMS paragraphs above, MIM paragraphs in this section serve as instances of a conversation and new

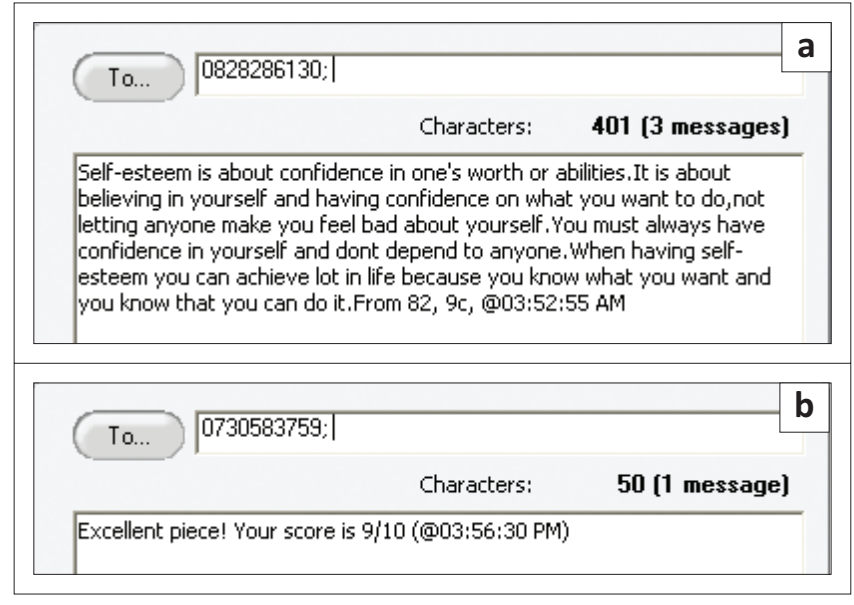

Note: The phone numbers of the participants are intentionally removed to ensure their anonymity.

FIGURE 2: (a) Sample short message service paragraph by learner; (b) feedback short message service by research team. 
media writing. This is so in spite of some of them displaying some of the features identified under the first set. For that matter, all of these MIM paragraphs need to be viewed against the backdrop of the variables: incidental learning (Kabilan et al. 2010), social learning, presence learning, relationality (Chaka \& Ngesi 2010) and CHAT (Kang \& Gyorke 2008; Rambe 2010). As instances of both conversation and new media writing, these paragraphs are typified mostly by casualness, informality and incomplete thoughts.

When attempting to respond to these MIM topics, participants produced two sets of short MIM paragraphs. For example, the first set of paragraphs consists of paragraphs that make use of the conventional English orthography. These MIM paragraphs also bear the following classical writing features: full sentences, punctuation marks, correct spelling of most words, acceptable grammar, appropriate use of words, and proper tense use. Other features these paragraphs have are proper sentence construction (topic, introductory, supportive and concluding sentences), linking or transitional words, unity of ideas, and coherence. By contrast, the paragraph displayed in Figure 3 is striking for being a long run-on sentence which, except for the use of an apostrophe, is wholly unpunctuated. However, these two MIM paragraphs share one more feature in common: the absence of textisms.

\section{Discussion of findings}

Regarding the usefulness of the SMS and Mxit, the findings of this study revealed that these two applications served as virtual platforms for chatting, friendship, fun, establishing new friendships and for sourcing information and knowledge for participants. In the first instance, these two technologies - as examples of social media technologies - tend to function as socialisation platforms for participants; in the second instance, they appear to be information and knowledge sharing tools for participants. The use of SMSs for friendship purposes ties in with Porath's (2011) view that most teenagers, especially most American teenagers, regard their mobile phones as indispensable as they employ text messaging for connecting with their friends. The same sentiment is echoed by Thurlow (2003) who points out that most United Kingdom (UK) adolescents tend to use text messages for friendship maintenance. This finding is also supported by Bosch (2008) who conducted a similar study in Cape Town, South Africa. Bosch concluded that Mxit and mobile phones are used by Cape Town adolescents, particularly girls, for developing personal relationships as they are cost-effective. In the same vein, Kreutzer's (2009) pilot study reports that learners from a Cape Town secondary school indicated that they used mobile phones for personal communication purposes.

The findings of the study also revealed that some learners felt that SMS and Mxit should not be used at school because they
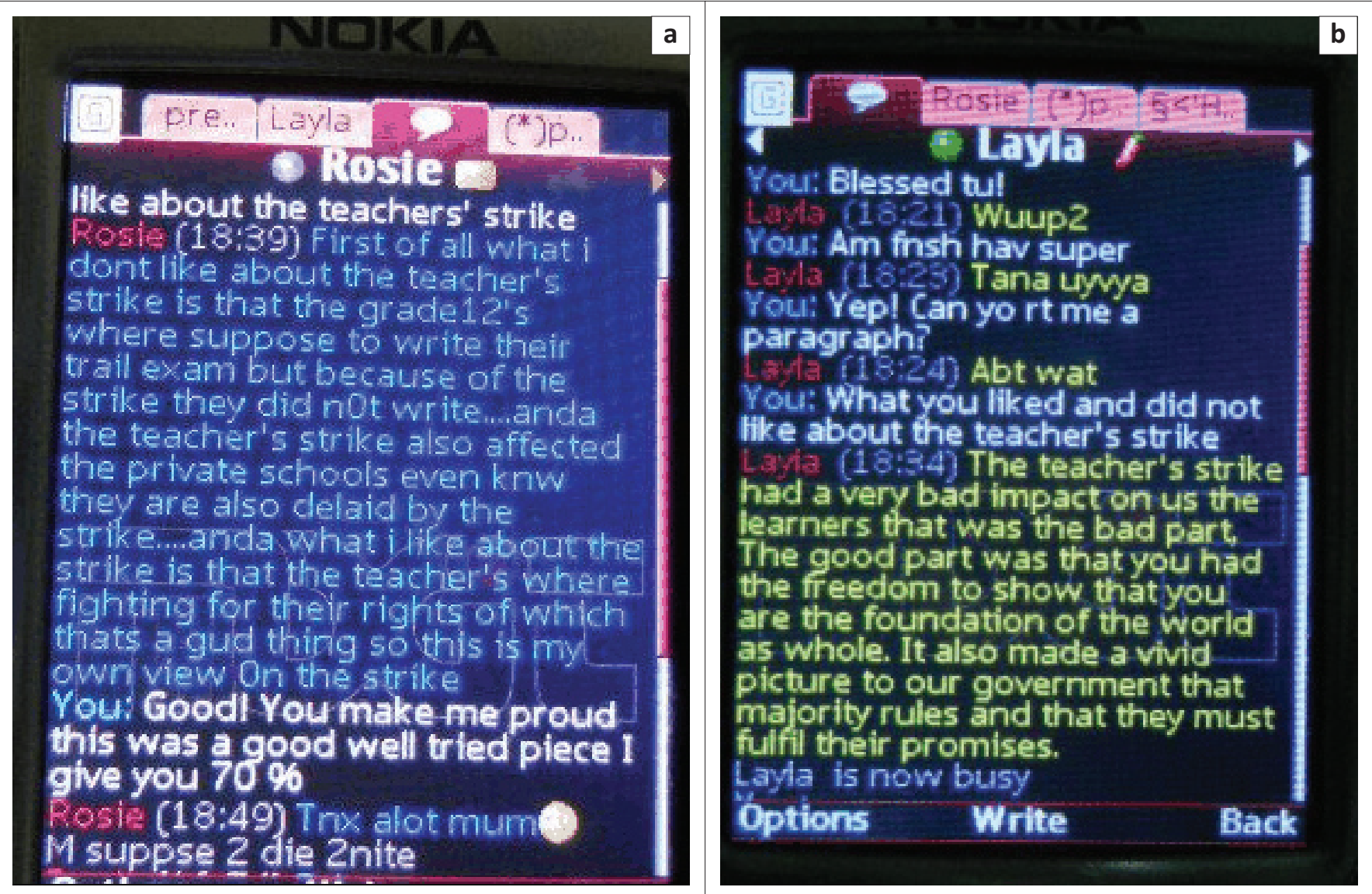

Note: The names of the participants are intentionally removed to ensure their anonymity.

FIGURE 3: Learner's Mxit mobile instant message: ( $a$ and $b$ ) sample mobile instant message paragraphs and feedback between learners and research team. 
were disruptive and were not part of the school curriculum. Participants' view that mobile phones and Mxit are disruptive at school and that they are not part of the school curriculum dovetails with the general practice of banning these technologies at most schools locally and abroad. For example, Porath (2011) states that mobile phones are banned in most $\mathrm{K}-12$ schools in the United States (US) as they are regarded as disrupting learning and interfering with it. Likewise, Mavhunga et al. (2016) make an observation that in most South African schools (both public and private) learners are required to switch off their mobile phones. She stresses that if learners are caught using their mobile phones, they (mobile phones) are immediately confiscated - and in some schools the confiscation can last for the whole year.

With regard to the use of SMS and Mxit language in their school work, participants revealed that they hardly used such language in their school work. The assertion that learners hardly use SMS and Mxit language in their school work has also been observed by Dansieh (2011). According to Dansieh, this assertion has much to do with the negativity generally associated with text messaging in formal school writing contexts. Such negativity is also reported, for instance, by Geertsema et al. (2011) in their project conducted at Gauteng's independent secondary schools.

The idea that mobile phones and Mxit could be used for additional and/or follow-up teaching and learning as expressed by participants in this study, tallies with Huang and Sun's (2010) project that used mobile technologies to support multimedia English listening in Japan. It also has a resonance with case studies reported by Valk, Rashid and Elder (2010) in which mobile phones were employed for teaching and learning purposes among school children in the non-formal distance sector of Philippines, Mongolia and Bangladesh. In the same breath, participants pointing out that mobile phones and Mxit serve as a space in which learners can freely communicate with their teachers seems to correspond with Begum's (2011) assertion that classes based on text message help shy learners interact with their teachers in a more free and relaxed manner than do face-toface classes.

The findings of the study also revealed that SMS paragraphs exhibit, in a way, both unity and coherence. This particular observation seems to correspond with Chaka and Ngesi's (2010) project on writing mobile phone paragraphs using SMSs by Grade 8 learners at one secondary school in Mthatha. It also reflects some of the elements that Oyinloye's (2009) project examined. However, the latter had a wider scope: it investigated whether mobile phones improved students' writing skills in essay writing at selected Nigerian senior secondary schools. In this case, its focus was on aspects such as expression, content generation, organisation, tense and punctuation. The study further revealed that participants' paragraphs lacked the usual textisms, both linguistic and contextual, characterising much SMS language. This is so despite the fact that participants submitted their paragraphs as SMSs. This observation seems to correspond with the view that most learners tend to avoid using textisms when required to produce formal writing (Vosloo 2009; Wood et al. 2009).

The study further revealed that the participants' MIM paragraphs had the potential to facilitate both incidental and social learning and helped participants to engage in these types of learning. The former entails learning per chance, or through errors (Kabilan et al. 2010) or through trial and experimentation. The latter relates to learning as a social activity (Chaka \& Ngesi 2010). For example, when participants write MIM paragraphs using Mxit, they are able to see one another's paragraphs and incidentally learn from one another's paragraphs as Mxit simultaneously displays all the texts of all the currently online or logged in participants. Incidental learning in this context is similar to classical observational learning. In the MIM paragraphs mentioned above, currently online participants are displayed in the small window panels atop each Mxit screenshot. Moreover, when writing MIM paragraphs, participants are able to engage in social learning as mediated by Mxit.

\section{Conclusion}

The study sought to explore the potential of mobile phones to improve students' access to learning material off the school environment. Specifically, the study sought to explore ways of increasing contact between learners and content in the target language. The study was also interested in establishing the views of learners pertaining being taught through mobile phones after the standard school hours and on the impact of these devices on the educational process. The results of the study proved that both mobile phones and Mxit are viable technologies to use for mobile supplemental teaching and learning purposes. This is more so as these two technologies proved to be not only viable but also sustainable in this study because of both their pervasive nature and their affordability. The study also demonstrated that text messaging in the form of SMSs and instant messaging in the form of MIMs can be used as mobile applications for mediating supplemental teaching and learning of EFAL to a group of Grade 9 learners at KJSS outside school hours. In this context, the study recommends that the use of these two mobile applications for supplemental teaching and learning purposes be explored at JKSS. This should not be confined to supporting the teaching and learning of EFAL but should include supporting the teaching and learning of other learning areas at JKSS as well.

The major limitation of the study is that the supplemental instruction activities were done while learners were at home. While the results are crucial for the integration of SMS and Mxit as technologies boosting learner contact with content in the target language, the study does not offer sufficient pointers on whether the integration of mobile phones in the school set up is possible, although of course very beneficial. Further research can explore the integration of mobile phones in core curricula activities during school time. In addition, research can explore the use of even more 
applications associated with mobile phones for instruction at different levels of the education system in South Africa and elsewhere and in relation to instruction in general and not just in EFAL cases.

\section{Acknowledgements}

The authors thank the learners who participated in the study.

\section{Competing interests}

The authors declare that they have no financial or personal relationships which may have inappropriately influenced them in writing this article.

\section{Authors' contributions}

Both N.N. and N.L. took the initiative to conduct the study. They were both responsible for conceptualising the title of the manuscript, collecting and analysing the data. N.M. was responsible for the introduction and wrote the first draft of the manuscript. M.P.C. was responsible for the discussion of findings and put the final draft of the manuscript together. B.T. was responsible for the methodology section and analysed the data. L.M.W. added to the literature review, refined the introduction and edited the manuscript.

\section{References}

Adjei, B.S., 2013, 'Discourse analysis: Examining language use in context', The Qualitative Report 18(Art. 50), 1-10, viewed 10 August 2014, from http://www. nova.edu/ssss/QR/QR18/adjei50.pdf

Al-Khalifa, H.S., 2008, Twitter in academia: A case study from Saudi Arabia, viewed 30 August 2009, from http://elearnmag.org/subpage.cfm?section=case studies\& article $=42-1$

Baxter, P. \& Jack, S., 2008, 'Qualitative case study methodology: Study design and implementation for novice researchers', The Qualitative Report 13, 544-559, viewed 10 May 2016, from http://www.nova.edu/ssss/OR/OR13-4/baxter.pdf.

Begum, R., 2011, 'Prospect for cell phones as instructional tools in the EFL classroom: A case study', International Journal on Integrating Technology in Education (IJITE) 5(1), 105-115.

Benbasat, I., Goldstein, D. \& Mead, M., 1987, 'The case research strategy in studies of information systems', MIS Quarterly 11, 369-386. https://doi.org/10.2307/ 248684

Borau, K., Ullrich, C., Feng, J.\& Shen, R., 2009, Microblogging for language learning Using Twitter to train communicative and cultural competence, viewed 12 February 2009, from http://www.carsternullrich.net/pubs/ICWL78.pdf.

Bosch, T.E., 2008, Wots ur ASLR? Adolescent girls' use of cellphones in Cape Town viewed 05 February 2010, from http://emerge2008.net/access/content/group/ emerge2008/PresentationFiles/Bosch/MXit-\%20Bosch.pdf

Brown, G. \& Yule, G., 1983, Teaching the spoken language, vol. 2, Cambridge University Press, Cambridge.

Brown, J.D.\& Rodgers, T.S., 2002, Doing second language research, Oxford University Press, Oxford.

Burak, L.J., 2012, Multitasking in the university classroom, In Movement Arts, Health Promotion and Leisure Studies Faculty Publications, Paper 74, viewed 06 April 2017, from http://vc.bridgew.edu/mahpls_fac/74.

Cameron, L., 2001, Teaching languages to young learners, Cambridge University Press, Cambridge.

Chaka, C. \& Ngesi, N., 2010, 'Mobile writing: Using SMSs to write short paragraphs in English', in R. Guy (ed.), Mobile learning: Pilot projects and initiatives, pp. 185-233, Informing Science Press, Santa Rosa, CA.

Chaka, C., Ramothea, L.\& Ngesi, N., 2010, 'Mobiles for learning (M4L) within education for social justice: Mobile phones and MXit', A Joint paper presented at the 3rd Research Colloquium (Education for Social Justice) held at the University of the Free State in Bloemfontein, 29-30th September.

Chaka, J.G. \& Govendor, I., 2017, 'Students' perceptions and readiness towards mobile learning in colleges of education: A Nigerian perspective', South African Journal of Education 37(1), Art.\# 1282, 1-12.

Churchill, D., Lu, J.\& Chiu, K.F.T., 2014, 'Integrating mobile technologies, social media and learning design', Educational Media International 51(3), 163-165. https://doi. org/10.1080/09523987.2014.969895
Dansieh, S.A., 2011,'SMS texting and its potential impacts on students' written communication skills', International Journal of English Linguistics 1(2), viewed 05 March 2018, from http://www.ccsenet.org/journal/index.php/ijel/article/ 05 March 2018, from http:
view/100502002003-paper.

Department of Education, 2003, Revised National Curriculum Statement Grades R-9 (Schools): Teacher's guide for the development of learning programmes (Languages), Government Printer, Pretoria.

Dunlop, J., 2017, Cellphones in the classroom, viewed [day, month and year] from http://www.childmag.co.za/content/cellphones-classroom\#.Wx5D7DXnHIU

Ed Technology Tours, 2017, Reimagining the Role of Technology in Education: 2017 National Education Technology Plan Update, U.S. Department of Education, viewed 05 September 2017, from http://tech.ed.gov

English, R. \& Duncan-Howell, J., 2008, Facebook@ goes to college: Using social networking tools to support students undertaking teaching practicum, viewed 19 February 2017, from http://eprints.qut.edu.au/15706/2/Facebook_goes_to college_Jennifer_Duncan_Howell.pdf.

Ford, M. \& Batchelor, J., 2007, From zero to hero - Is the mobile phone a viable learning tool for Africa?, viewed 08 March 2010, from http://www.nqf.org.za/ download_files/nqf-support/11\%20Ford \%20Batchelor_From $\% 20$ zero $\% 20$ to $\% 20$ hero.pdf

Freudenberg, K., 2009, 'Investigating the impact of SMS speak on the written work of English first language and English second language high school learners', Master's thesis, Stellenbosch University.

Fried, C.B., 2008, 'In-class laptop use and its effects on student learning', Computers \& Education 50(3), 906-914. https://doi.org/10.1016/j.compedu.2006.09.006

Geertsema, S., Hyman, C.\& Van Deventer, C., 2011,'SMS language and written language problems: Educators' perspectives', South African Journal of Education 31(4), 475-487. https://doi.org/10.15700/saje.v31n4a370

Godwin-Jones, R., 2017, 'Smartphones and language learning', Language Learning and Technology 21(2), 3-17.

Hagos, L.C., 2008, Enhancing teaching and learning through SMS-mediated lectures in mathematics, viewed 08 September 2010, from http://www.cs.cityu.edu. $\mathrm{hk} / \sim$ ichl2008/local-proceedings/ICHL2008-PP033-042-10Pages.pdf.

Haruna, R., Aisha, I.M., Yunusa, U. \& Hadiza, T.A., 2016, 'Impact of mobile phone usage on academic performance among secondary school students in Taraba State, Nigeria', European Scientific Journal 12(1), 466-479.

Hatter, J.M., 2002, The application of exchange theory to internet relay chat, viewed 04 June 2012, from http://www.birmingham.ac.uk/Documents/college-artslaw/ cels/essays/matefltesldissertations/HatterDiss.pdf

Henning, E., Van Rensburg, W. \& Smit, B., 2004, Finding your way in qualitative research, Van Schaik, Pretoria.

Huang, C. \& Sun, P., 2010, Using mobile technology to support multimedia English listening exercises in daily life. The International Conference on Computer and Network Technologies in Education, viewed 06 April 2014, from: http://search. shamaa.org/PDF/Articles/EGJrciet/JrcietVol1No3Y2015/jrciet_2015-v1-n3_039059 eng.pdf

Jairus, E.U., Christian, U.U., Ogwuche, A.J., Thomas, O.I., Tyavlum, T.T., Ode, E.J. et al., 2017, 'Impact of mobile phone usage on students' academic performance among public secondary schools in Oju local government area of Benue State, ljsrm Human 6(3), 104-118.

Johansson, R., 2003, 'Methodologies in housing research', In Conference Keynote at the Royal Institute of Technology and International Association of PeopleEnvironment Studies, Stockholm, 22-24th September.

Junco, R., 2012, 'In-class multitasking and academic performance', Computers in Human Behavior 28(6), 2236-2242. https://doi.org/10.1016/j.chb.2012.06.031

Kabilan, M.K., Ahmad, N. \& Abidin, M.J.Z., 2010, 'Facebook: An online environment for learning of English in institutions of higher education?', The Internet and Higher Education 3(4), 179-187, viewed 21 March 2012, from http://pinarmanici. files.wordpress.com/2011/04/facebook1.pdf

Kang, H. \& Gyorke, A.S., 2008, 'Rethinking distance learning activities: A comparison of transactional distance theory and activity theory', Open Learning 23(3), 203-214. https://doi.org/10.1080/02680510802420050

Kimura, M., 2007, Mobile learning using mobile phones in Japan. Tokyo Women's Medical University, Japan, IGI Global, 1/5/2007, viewed 06 April 2014, from www. igi-global.com/

Kreutzer, T., 2009, 'Assessing cell phone usage in a South African township school, University of Cape Town, South Africa', International Journal of Education and Development using Information and Communication Technology (IJEDICT) 5(5), Develop 57.

Laurillard, D., 2007, 'Pedagogical forms of mobile learning: Framing research questions', in N. Pachler (ed.), Mobile learning: Towards a research agenda, pp. 153-175, WLE Centre, London, UK.

Ling, R. \& Baron, N.S., 2007, Text messaging and IM: Linguistic comparison of American college data, viewed 24 November 2010, from http://www1.american.edu/tesol/ Mechanics

Ling, R. \& Bertel, B., 2013, 'Mobile culture among children and adolescents', in D. Lemish (ed.), The Routledge Handbook of Children, Adolescents and Media, pp. 127-133, Routledge, New York.

Mail \& Guardian, 2012, iPads bring 'new attitude to learning' at schools, M \& G Media viewed [day, month and year] from, https://mg.co.za/article/2012-04-02-ipadsbring-new-attitude-to-learning-at-schools/

Mavhunga, F.Z., Kibirige, I., Chigonga, B. \& Ramaboka, M., 2016, 'Smartphones in public secondary schools: Views of matric graduates', Perspectives in Education 34(3), 72-85. https://doi.org/10.18820/2519593X/pie.v34i3.6 
Meurant, R.C., 2007, 'Using cell phones and SMS in second language pedagogy', Journal of Convergence Information Technology 2(1), 98-106, viewed 02 December 2010, from http://www.nysaflt.org/conferences/summerinstitute/ doc December 2010, from http://www.nysaflt.org/confer

North, D., Johnston, K. \& Ophoff, J., 2014, 'The use of mobile phones by South African university students', Issues in Informing Science and Information Technology 11 115-138, viewed 23 August 2016, from http://iisit.org/Vol11/IISITv11p115138North0469.pdf

Oyinloye, G.O., 2009, Assessing the need for mobile communication mediated instructional strategy in the teaching of writing skills, viewed 02 November 2009, from http://medwelljournals.com/fulltext/ijsc/2009/39-44.pdf

Palalas, A., 2011, 'Mobile-assisted language learning: Designing for your students', in S.S. Thouesny \& L Bradley (eds.), Second Language teaching and learning with technology: Views of emergent researchers, pp. 71-94, Research Publishing.net. Dublin, Ireland.

Parr, C., 2013. Africa's mobile phone e-learning transformation, viewed n.d., from https://www.timeshighereducation.com/features/africas-mobile-phone-elearning-transformation/2007120.article

Porath, S., 2011, 'Text messaging and teenagers: A review of the literature', Journal of the Research Center for Educational Technology 7(2), 86-99.

Project Tomorrow, 2010, Unleashing the future: Educators 'Speak up' about the use of emerging technologies for learning, viewed 19 February 2012, from http://www. tomorrow.org/speakup/pdfs/SU09UnleashingTheFuture.pdf

Rambe, P., 2010,'Using contradictions to ravel teaching and learning challenges in a blended IS course in an African university', Journal of Information, Information Technology, and Organizations 5, 101-124, viewed 23 February 2012, from http:// www.jito.org/articles/JIITOv5p101-124Rambe461.pdf.

Rowley, J., 2002, 'Using case studies in research', Management Research News 25(1), 16-27. https://doi.org/10.1108/01409170210782990

SAIDE, 2008, Using mobile technology for learner in Open Schooling, viewed 18 November 2009, from http://www.col.org/SiteCollectionDocuments/

Sana, F., Weston, T. \& Cepeda, N., 2013, 'Laptop multitasking hinders classroom learning for both users and nearby peers', Computers and Education 62, 24-31. https://doi.org/10.1016/j.compedu.2012.10.003

Schroeder, J. \& Greenbowe, T.J., 2009, The chemistry of Facebook: Using socia networking to create an online community for the organic chemistry laboratory viewed 18 June 2009, from http://www.uh.cu/static/documents/AL/The $\% 20$ Chemistry\%20offacebook.pdf

Shapshak, T., 2015a, “'Please Call Me” saga reveals South Africans' special ingenuity', Rand Daily Mail, viewed 05 December, 2015, from http://www.rdm.co.za/technology/ 2015/06/05/please-call-me-saga-reveals-south-africans-special-ingenuity

Shapshak, T., 2015b, Why WhatsApp is South Africa's Favourite App, Forbes.com viewed 27 January 2016, from http://www.forbes.com/sites/tobyshapshak/ 2015/09/04/why-whatsapp-is-south-africas-favourite-app/2/\#2eb87c986dae

Sharples, M., Taylor, J.\& Vavoula, G., 2005, 'Towards a theory of mobile learning', paper presented at MLEARN, European Workshop on Mobile and Contextual Learning, University of Birmingham, 20-21st June.

Shi, S., Mishra, P., Bonk, C.J., Tan, S. \& Zhao, Y., 2006, Thread theory: A framework applied to content analysis of synchronous computer mediated communication data, viewed 04 June 2012, from http://www.itdl.org/Journal/Mar_06/article02.htm
Sinclair, J. \& Coulthard, M., 1992, 'Towards an analysis of discourse', in M. Coulthard (ed.), Advances in spoken discourse analysis, pp. 1-34, Routledge, London.

Stone, A. \& Briggs, J., 2002, 'ITZ GD 2 TXT - How to use SMS effectively in m-learning', Proceedings of the European Workshop on Mobile and Contextual Learning, 20-21 June 2005, University of Birmingham.

Strydom, H. \& Delport, C.S.L., 2001, 'Sampling and pilot study in qualitative research', in A.S. De Vos, H. Strydom, C.B. Fouche \& C.S.L. Delport (eds.), Research at grassroots: For the social sciences and human service professions, pp. 333-338, Van Schaik, Pretoria.

Stubbs, M., 1983, Discourse analysis: The sociolinguistic analysis of natural language, Basil Blackwell, Oxford.

Tagliamonte, S.A. \& Denis, D., 2008, Linguistic ruin? Lol! Instant messaging and teen language, viewed 24 November 2010, from http://americanspeech.dukejournals. org/cgi/reprint/83/1/3.pdf

Tannen, D., 1984, Conversational style: Analyzing talk among friends, Ablex Nor'wood, NJ.

Thurlow, C., 2003, Generation Txt? Exposing the sociolinguistics of young people's text messaging, viewed 05 December 2013, from http://extra.shu.ac.uk/daol/articles/ v1/n1/a3/thurlow

Thurlow, C., Lengel, L. \& Tomic, A., 2004, Computer mediated communication: Social interaction and the Internet, Sage Publications Ltd., London.

UNESCO, 2017, Supporting teachers with mobile technology. Lessons drawn from UNESCO projects in Mexico, Nigeria, Pakistan and Senegal, United Nations Educational, Scientific and Cultural Organization, France, Paris.

Valk, J.H., Rashid, A.T. \& Elder, L., 2010, 'Using mobile phones to improve educational outcomes: An analysis of evidence from Asia', The International Review of Research in Open and Distance Learning 11(1), viewed 06 April 2014, fromhttp:// www.irrodl.org/index.php/irrodl/article/view/794/1487

Van Dijk, T.A., 1995, 'Discourse analysis as ideology analysis', in C. Schaffer \& H.K. Holmes (eds.), Language and peace, pp. 17-33, Aldershot, Dartmouth.

Van Weert, T., 2005, 'Lifelong learning in knowledge society: Implications for education', in T.J. van Weert (ed.), Education and the knowledge society: Information technology supporting human development, pp. 15-25, Kluwer Information technology supporting
Academic Publishing, Boston, MA.

Vosloo, S., 2009, The effects of texting on literacy: Modern scourge or opportunity? viewed 15 March 2010, from http://vosloo.net/wp-content/uploads/pubs/ texting_and_literacy_apr09_sv.pdf

Weiss, K.J., 2009, An exploration of the use of text messaging by college students and its impact on their social and literacy behaviors, viewed 30 January 2018, from https://curve.coventry.ac.uk/open/file/059ffa92debc-ef21-7ea5. woodeffect1.pdf

Wood, C., Jackson, E., Plester, B. \& Wilde, L., 2009, Children's use of mobile phone text messaging and its impact on literacy development in primary school, viewed 24 September 2010, from http://partners.becta.org.uk/upload-dir/downloads/ page_documents/research/reports/childrens_use_of_mobile_phone_text_ messaging.pdf

World Economic Forum, 2017, The future of jobs and skills in Africa: Preparing the region for the fourth industrial revolution, viewed 20 January 2018 from: https:// www.weforum.org/reports/the-future-of-jobs-and-skills-in-africa-preparing-theregion-for-the-fourth-industrial-revolution 